\title{
Understanding China's changing engagement in global climate governance: a struggle for identity
}

\author{
Jilong Yang ${ }^{1}$
}

Received: 15 February 2021 / Revised: 13 September 2021 / Accepted: 12 November 2021/

Published online: 8 January 2022

(c) The Author(s), under exclusive licence to Springer-Verlag GmbH Germany, part of Springer Nature 2021

\begin{abstract}
This article offers a novel understanding of China's changing engagement in global climate governance over the past decade. This article argues that China has embedded the construction of its international identity, which has been transforming towards what this article conceptualizes to be a 'Yinling leading power', in promoting and leading global climate governance. China's transforming identity construction has contributed to changing its construction of climate justice and led China to proactively undertake more responsibilities, provide international public goods and promote international climate cooperation. Global climate governance has become one of China's prototypical discursive frames in constructing its new international identity, an important platform where China seeks to share leadership with other major powers and the climate leadership in turn constitutes China's new identity. However, China's inadequate response to international expectations and lack of self-reflection in its climate policy have influenced international recognition on its climate leadership and new identity. In general, China's transforming identity construction and its reconstruction of climate justice have far-reaching implications for China and Europe to cooperate and coordinate in strengthening global climate justice and promoting global climate governance.
\end{abstract}

\section{Introduction}

China 'will never accept the idea that the Chinese people can only enjoy one third, one fourth or even one fifth of the rights and interests of the people of developed countries'. China 'cannot blindly accept that protecting the climate is humanity's common interest' (Yu Qingtai, China's special envoy on climate change, 2009b, 2010).

Jilong Yang

y.j.l.yang@vu.nl

1 Department of Political Science and Public Administration, Vrije Universiteit Amsterdam, Amsterdam, The Netherlands 
We have acted as a responsible major power and played an important leadership role in enhancing global cooperation on climate change (Wang Yi, China's Foreign Minister, 2015).

From the failure of the Copenhagen Climate Summit in 2009 to the adoption of the Paris Climate Agreement in 2015, global climate governance (GCG) has entered into a new phase with 'a decisive break from the unsuccessful Kyoto regime' (Keohane and Oppenheimer 2016: 142). Global climate justice is an underlying issue and 'unavoidable' part of international climate politics (Audet 2013; Harris et al. 2013; Okereke and Coventry 2016; Shue 1992). The failures and successes of international climate negotiations on shaping the design and evolution of the climate regime have much to do with the social construction of climate justice and the idea of a fair climate deal (Audet 2013). Within the process of constructing a fair global climate deal from Copenhagen to Paris, China's role has undergone a significant shift.

At the Copenhagen Climate Summit in 2009, China insisted on its longstanding rigid stances of refusing to accept binding targets to reduce its greenhouse gas emissions and argued from the perspective of equity that developed countries caused the climate change problem and should take the lead in addressing climate change while developing countries have the right to development and should be exempted from binding emission reduction targets (Harris et al. 2013). In the pre- and post-Paris era, however, China has actively engaged in considerable international cooperation to reach and implement the Paris Agreement, and at the same time has significantly increased domestic climate actions (Belis et al. 2015). China has embraced international climate leadership (Engels 2018; Tiberghien 2018).

Given that China had persistently rejected international leadership in international affairs for decades, how can we understand China's changing engagement in global climate governance? Especially, China's embrace of international climate leadership is actually part of a much broader shift in its overall foreign policy and its positioning in global governance more generally. Over the past decade, China's foreign policy strategy has shifted from Tao Guang Yang Hui (keeping a low profile) to Fen Fa You Wei (striving for achievement) (Yan 2014).

The existing scholarly work has identified a number of domestic and international factors that impact China's climate practices, including economic growth (Ong 2012), energy security (Conrad 2012), severe air pollution and environmental problems (Schreurs 2016), international reputation and image (Belis and Schunz 2013), the 'New Normal' of economic development (Dong 2017; Hilton and Kerr 2017), technological innovation and development in renewable energy (Heggelund 2021) and the changing international negotiating context (Tiberghien 2018). All these factors and their interplay have indeed contributed to China's changing climate practices. This article does not negate the importance of these factors in understanding China's presence in global climate governance. But this article will show that the qualitative change in China's international role as transpires from the case of global climate governance is also related to China's changing construction of its international identity. In international studies, constructivists stress that one cannot comprehensively understand a state's foreign policy behaviours without taking identity into account, and argue that identity can mediate and shape a state's understanding 
about international issues (such as global climate governance) and can shape, enable and constrain the state's policy behaviours (Wendt 1999). A state's foreign policy can be seen as its identity constructing performance (Messari 2001: 235-237). Many existing studies that focus on material circumstances treat China's changing climate practices as a mechanical act of rational adaptation to its domestic and external material circumstances, thus missing the meaning and implication of how China communicates itself to the world. In addition, the importance of China's presence in promoting justice in the climate governance regime is also neglected (Stalley 2013).

Furthermore, climate justice is a 'discursive battlefield' where states define themselves and others (Audet 2013: 370). Namely, states define and justify their international identities through discursively constructing climate justice and related issues. During the early period of climate change governance, China had constructed its developing country identity and justified its rigid positions through persistently stressing historical responsibilities of developed/industrialized countries and framing developing countries as innocent and more vulnerable to climate change (Harris et al. 2013: 298). Climate change was always framed by China as a problem that developed countries should address first and China kept a low profile in climate change governance. With China's transformation towards international climate leadership over the past decade, how has China constructed its international identity through discursively constructing issues of climate justice in shaping the climate regime?

In order to address these questions, this article focuses on China's construction of its international identity in its climate policy discourses and practices and examines the ways in which identity and related political discourses are deployed in China's changing engagement in global climate governance from Copenhagen to Paris. The data mainly consist of Chinese political leadership's speeches and statements, China's high-level climate negotiators' speeches, official documents, 1467 editorials of China's state-owned newspaper-People's Daily, reports of third-parties such as Earth Negotiations Bulletin (ENB), secondary literatures and news reports. Additionally, 20 individual in-depth semi-structured expert interviews were conducted in 2017 and 2018. Interviewees were Chinese and the EU climate negotiators, diplomats, NGOs, scholars and experts of the United Nations Intergovernmental Panel on Climate Change.

This article finds that China has embedded the construction of its new international identity in leading global climate governance in the Paris era and beyond. This changing identity construction is both reflected in and partly constituted by the way China has come to take up its new leadership role in GCG. Climate change governance has become one of China's prototypical discursive frames in constructing its new international identity. China has reconstructed issues of climate justice and GCG has become an important platform where China seeks to represent itself as a leading actor and share leadership with other major powers.

This article is laid out as follows: The first section lays the theoretical basis of international identity and global climate justice. The second section presents research design. The third section investigates China's international identity construction from 2009 to 2019. In the fourth section, this article examines China's engagement in GCG on the road to Copenhagen. The fifth section analyses China's 
new identity construction through its changing engagement in GCG in the pre- and post-Paris era. Then, the sixth section discusses the implications of China's transformation and the last section concludes.

\section{Identity construction and global climate justice}

Constructivists in IR stress that identity tells a state who it is, defines the social relationships between the state and others, and offers relatively stable understandings of each state's motives, probable actions and roles in given situation (Hopf 1998; Wendt 1999). Identity is not pre-given but socially constructed and always in a process of constructing and reconstructing (Wendt 1999). In this study, a state's foreign policy discourses and practices are regarded as a process of constructing its international identity (Messari 2001; Wendt 1999). Identity is sustained by social interactions and a state has to seek recognitions from others so that its identity can be secured and it can maintain a relatively stable sense of Self (Wendt 1999).

In international climate politics, climate justice is a 'discursive battlefield' where states define themselves and others (Audet 2013: 370). While the concept of climate justice does not exclusively look at states, the main discourses surrounding climate justice in international climate negotiations are rooted in a fundamental truth that developed countries have historically caused the climate change problem, the consequences of climate change on different countries and regions are uneven, and the ability of rich and poor countries to bear the cost of addressing climate change is immensely different (Audet 2013; Harris et al. 2013; Okereke and Coventry 2016). Despite a wide range of definitions and typologies of global climate justice, questions of fairness and equity in addressing climate change have dominated international climate negotiations for decades. But the perceptions of what constitutes a fair/just way to deal with climate change are often quite different between for instance the EU/the North and developing countries (Okereke and Coventry 2016; von Lucke et al. 2021). Contestations for fairness and equity are also entangled with other factors such as economic interests and climate science (Okereke and Coventry 2016). Shaping the design and evolution of the climate governance regime is largely about addressing the issues regarding "what to do, who should do it and how, and who would pay for it' (Dimitrov 2010: 800). States socially construct global climate justice through debating what global climate justice entails and how it can be achieved in solving these key issues. Within this social construction process of global climate justice, states communicate themselves to each other and define their identities.

Climate justice concerns are reflected in the principles and provisions of the distinction between annex I and non-annex I countries incorporated in the established climate regime - the United Nations Framework Convention on Climate Change (UNFCCC) and its Kyoto Protocol. Key elements such as the equity principle of common but differentiated responsibility (CBDR) between developed and developing countries, the notion of historic and per capita emissions, and the North-South technology and financial transfers constitute the cornerstones of the justice dimension of the climate regime (Okereke and Coventry 2016). Issues of climate justice 
remain crucial in shaping a fair climate regime deal for the post-Kyoto period in light of the changing emissions landscapes and national circumstances.

\section{Research design}

In order to examine China's changing engagement in GCG through the lens of identity, this article will firstly examine the changes of China's overall construction of its international identity - who China is in the international community. This is mainly done through a content analysis that provides both qualitative assessment of the Chinese leadership's view (how China is referred to and which characteristics are ascribed to it discursively) and quantitative measure (frequency of appearance in China's official narratives), given that the Chinese leadership within China's domestic political system holds the monopoly on defining China's international identity. This article will use those key Chinese-coined concepts offered and used by China's leaders in describing China's international presence as key terms to search in the two types of editorials of People's Daily - the largest and most influential state-owned newspaper in China and then count their frequency. The two editorials named as Zhongsheng and Guojiping are the main editorials that People's Daily comments on China's foreign policy and international affairs. From 2009 to 2019, it issued 1413 Zhongsheng articles and 54 Guojiping articles.

After characterising China's overall construction of its international identity, this article will examine China's changing engagement in shaping the post-Kyoto regime in two main dimensions. Firstly, China's discursive construction. In China's climate narratives, how China is referred to and what kind of characteristics are ascribed to China discursively, and how China frames climate change governance and issues of climate justice in particular. By focusing on these discursive aspects, this article will specifically examine speeches of China's leadership and climate negotiators, official policy documents, state-owned newspapers and interview data. Secondly, China's policy practice. By focusing on China's domestic and international climate policy behaviours and its climate diplomacy within international climate negotiations, this article will investigate how China's role in climate governance has changed, how China interacts with other actors and how the significance of climate change governance in China's global presence has changed.

\section{China's transforming construction of international identity}

China has represented itself as a major developing country for decades. When China went into the first decade of 2000s, China's then President Hu Jintao (2004, 2011) still firmly insisted to represent China as a 'major developing country' with 'poor' and 'underdeveloped' material capability and mainly positioned China as a 'participant' in international affairs. Hu's administration persistently opposed any suggestions for revising China's developing country identity and rejected the idea of 'G2' that the USA and China co-lead the world (Brzezinski 2009). In line with this 
developing country identity, China kept a low profile in international affairs (Men H 2014; Pu 2017).

However, with China's rapid rise, domestic and international expectations for a greater global presence of China have greatly increased, and at the same time doubts towards China's developing country identity have significantly arisen ( $\mathrm{Pu} \mathrm{2017}$; Shambaugh 2011). China's increasing material strength, unwillingness to take up more international responsibilities and assertive behaviours in its territorial disputes generated confusions, concerns and even fears to its Asian neighbours about its role in the region order as well as in the international order (Mearsheimer 2010; Yan 2014). With accession to power in 2012/2013, Xi Jinping attempted to offer a new definition of China's international identity. While the 'old' discourses of developing country identity still have traction domestically ( $\mathrm{Pu} 2017$ ), China's self-ascribed international identity has been frequently conveyed in a very new Chinese term'yinlingzhe' (a leading state) which had seldom appeared in China's national narratives regarding its international presence in the past. Xi (2014, 2016a) repeatedly stressed that China should be a global 'yinlingzhe' rather than just be a 'follower' or 'bystander' in 'defining international rules' and 'reforming the global governance system'. But interestingly, Xi did not use another more common Chinese term'lingdao' which has very similar meanings of the English word-leader. In Chinese, the nuance between the term 'yinlingzhe' and 'lingdao' is that the latter highlights the hierarchy structure between a leader and followers while the former not. Moreover, 'yinlingzhe' contains the meanings and connotations of pioneer, vanguard and leading actor, and the status that a 'yinlingzhe' holds is not exclusive whereas with 'lingdao', it is exclusive. As a global yinlingzhe, emphasized by $\mathrm{Xi}$, China will 'proactively undertake more international responsibilities' (Xi 2013), continue to support multilateralism and international multilateral institutions (Xi 2015b, 2016b), and cooperate with others in a way of 'extensive consultation, joint contribution and shared benefits' (gongshang, gongjian, gongxiang) in order to establish a regional and global 'community of common destiny for mankind' (renlei mingyun gongtongti) (Xi 2017a, b) —China's conception of international society. In Xi's vision, furthermore, a global yinlingzhe is very different from a hegemony because China aims to 'co-define international rules' and 'co-govern global affairs' with other international players and will 'never seek hegemony' (Xi 2012, 2017a). Xi actually discursively constructed China as a global leading actor who pursues a shared leadership. While some critics may just treat these discursive representations as China's propaganda, these official discourses do show how China communicates itself to the world and entail China's understanding about the relationship between itself and the existing international order.

At the same time, the term yinlingzhe has also become a buzz word in China's official narratives. In September 2019, for instance, China issued a white paper China and the World in the New Era and framed itself as a yinlingzhe in 'reforming and developing the global governance system' (State Council 2019). Since Xi's rise to power in 2012/2013, as shown in Fig. 1, the term 'yinlingzhe/yinling' (noun/verb) has been used much more frequently in Peoples' Daily's editorials (Zhongsheng and Guojiping). The decrease in 2019 could be the side-result of the 


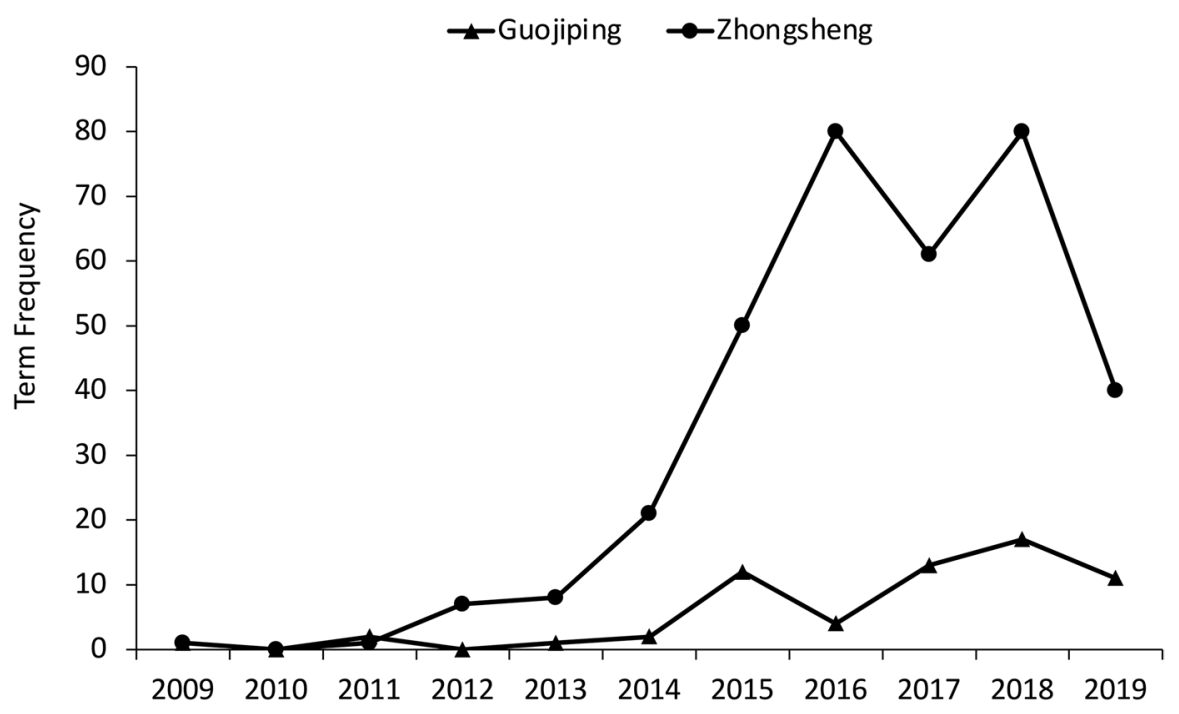

Fig. 1 Term frequency of 'yinlingzhe/yinling' (2009-2019)

increasingly worsening US-China trade war which took up the most attention of the two editorials.

Chinese IR scholars contributed to the further explication and construction of the yinlingzhe concept: (1) China seeks to be a global leading power rather than a regional or global hegemony (Pang 2018); (2) shouldering international responsibility and offering international public goods (Men 2017); (3) binding and constraining itself in international multilateral institutions (Pang 2018); (4) pursuing an open, stable and institutions-based global order (Chen 2017).

To sum up, Chinese leaders and academics deliberately differentiated China from traditional hegemonies and superpowers and discursively constructed China as a new type of global leading power which exercises a shared leadership. Different from the pure self-centred and unilateral leadership, China's conceptions of a shared leadership particularly emphasize that international actors co-define international rules and co-govern global affairs through consensus-making, jointly promote the reform of the multilateral order of global governance and build a community of common destiny for mankind. Additionally, China's yinlingzhe style, which is partially in line with Robyn Eckersley's account of leadership, approaches leadership as a form of social interaction whereby leading states guide, attract or negotiate 'the consent or acquiescence of other parties', 'enable or facilitate collective action towards the achievement of a common purpose in a given community' (Eckersley 2020: 1184). In this article, I coin this new yinlingzhe representation as a new Yinling Leading Power identity. It should be noted that this Yinling Leading Power identity is an ideal-type. From a constructivist perspective, the ultimate result of this new identity construction heavily relies on the recognition of other international actors. 


\section{The road to Copenhagen}

From 2005 onward, the international community debated on whether adopting a new single and comprehensive global agreement that addresses both developed and developing countries' emissions when the Kyoto Protocol's first commitment period expired in 2012 or extending the Protocol with a second commitment period. A political deadline for reaching a solution was set in December 2009- the Copenhagen Climate Summit. With its booming greenhouse gas emissions, China was 'pushed to the forefront' in international climate politics (Men J 2014: 54). The following sections will examine how China constructed and maintained its developing country identity on the road to Copenhagen.

\section{Discursive construction}

From the onset of the 'Reform and Opening-up' policy in the 1980s, integrating itself into the international community was a priority of China's foreign policy. After the Tiananmen incident in 1989, however, China's relations with Western countries sharply deteriorated. At that time, international climate negotiations under the UN were high profile international negotiations (Kobayashi 2003). Through joining the UNFCCC and showing its respect of international (environmental) norms, China alleviated the diplomatic tensions with the Western world (Conrad 2012).

Nevertheless, from the very beginning, China approached climate change through climate equity, constructed climate change as a North-South issue and connected to global historical inequality, regarded international climate negotiations as a North-South struggle, and discursively differentiated the South from the North in negotiations (Conrad 2012; Harris et al. 2013). Since the 1990s, China's top leaders like the then Premier Li Peng (1992) and Wen Jiabao (2007) persistently represented China as a part of the developing world and stressed that the developing South was a 'poor' and 'innocent victim' of climate change and vulnerable to its adverse impacts while the North has the main historical responsibility to the climate change problem. Furthermore, besides stressing the equity principle through highlighting its own lower per capita emissions (Wen 2007), China framed the North's emissions as 'luxury emissions' while recognising the emissions of the South as 'survival/development emissions' (ENB 1997: 9; Wen 2007). This argument is compatible with Henry Shue's conceptions of climate justice regarding emissions (Shue 1993). China repeatedly stressed that economic development and poverty eradication were 'top priorities' of developing countries and the international efforts to fight climate change 'should promote, not block, the economic development and poverty eradication' (Li 1992; Wen 2007). Shouldering climate responsibility was actually seen by China and other developing countries as a heavy burden that would impact their economic development (Ong 2012). China continued to keep and promote the CBDR principle at the forefront of international climate debates (Stalley 2013). China's discursive constructions of climate change were widely shared by developing 
countries (Stalley 2013). In particular, the G77-a broad coalition of developing nations including many Asian countries_-stood with China, supported those constructions and regarded China as the leader of the G77/China group (Kasa et al. 2008). China defended the shared developing country identity of the developing world and maintained climate change as a marginal issue on its agenda.

On the road to Copenhagen, China attempted to maintain its developing country identity and defend its rigid positions through highlighting its construction of issues of climate justice. Before the Copenhagen Summit, for example, China's Special Envoy for climate change-Yu (2009a) emphasized that 'no matter China or Bahamas, as the developing countries, we are both victims' and it is unfair to require developing countries to 'undertake similar obligations with those of developed countries'. Yu (2009b) also argued that China 'will never accept the idea that the Chinese people should only enjoy one third, one fourth or even one fifth of the rights and interests of the people of developed countries'. At the Summit, China's Premier Wen Jiabao stated:

Developing countries only started industrialization a few decades ago and many of their people still live in abject poverty today. It is totally unjustified to ask them to undertake emission reduction targets beyond their due obligations and capabilities in disregard of historical responsibilities, per capita emissions and different levels of development. Developed countries, which are already leading an affluent life, still maintain a level of per capita emissions that is far higher than that of developing countries, and most of their emissions are attributed to consumption. In comparison, emissions from developing countries are primarily survival emissions and international transfer emissions (Wen 2009).

The former European chief climate negotiator-Bert Metz-mentioned that China's climate negotiators had even claimed that 'China will always remain a developing country, and don't expect us ever to be one Annex I country' (Interview 2018). The North-South divide remained as the core of China's understanding and construction of climate change. At the same time, China firmly rejected to represent itself as an international climate leader (Conrad 2012). In Copenhagen, China's then Vice Foreign Minister He Yafei (2009) stressed that the so-called China-US co-leadership in climate governance has 'no legal basis' and 'is far from the truth' in reality.

However, China's rapid development and booming carbon emissions changed many countries' perceptions of China and China's developing country identity construction suffered challenges from both the North and South in Copenhagen (Conrad 2012). The EU differentiated China from other 'ordinary' developing countries and defined China as an 'economically more advanced developing country' that should undertake more international responsibilities (European Commission 2009). Moreover, many G77 members, including Asian countries, and several major developing countries such as Mexico and Argentina also shared this perception and requested China and other major emitters to bear more international responsibilities (Kastner et al. 2018; Stalley 2013). 


\section{Policy practice}

Since the 1990s, China has allied itself with the G77 which includes many Asian countries in international climate negotiations and operated the G77/China coalition as a coordinating body for developing countries to form common stances (Kasa et al. 2008). At the Copenhagen Summit, however, the developing world split. For instance, many countries from the AOSIS, Latin America and Africa stood with many developed countries to demand for a new legally binding deal, while China responded with a rather harsh objection and urged a focus on implementing the existing commitments under the Convention and Protocol (ENB 2009). China established a new coalition-the BASIC group with another three emerging economies and acted jointly to defend the CBDR principle and reject legally binding obligations on them (Hochstetler and Milkoreit 2014). The Copenhagen Accord - the final political text reached by the BASIC countries and the USA - was just 'taken note' by the Conference Plenary because of the opposition of some developing countries (Dimitrov 2010).

In negotiations, China insisted on the strict differentiation framework enshrined in the UNFCCC and the Protocol and steadfastly opposed any 'intrusive' institutional arrangements that impose binding targets on the South (Christoff 2010; Conrad 2012). In Copenhagen, China's Wen Jiabao (2009) and He Yafei (2009) insisted that its voluntary commitment under the UNFCCC was 'unnegotiable' and the Copenhagen conference should 'stick to rather than obscure the basic principles enshrined in the Convention and the Protocol', and particularly, the CBDR principle 'must never be compromised'. China resisted any initiatives that may directly or indirectly impose a cap for its emissions and restrict its future 'emissions space' (Christoff 2010: 648). When developed countries requested China's mitigation actions to meet international 'measurable, reportable and verifiable' standards, China strongly rejected international scrutiny on its voluntary mitigation actions and stuck to protecting its sovereignty (He 2009). China insisted that developed countries should play the leadership role and pay for the costs for a cooperative solution (NDRC 2009). At last, China's rigid and tough tactics in its climate diplomacy in Copenhagen received widely international criticism (Christoff 2010). China's developing country identity became hard to continue in GCG.

\section{The Paris era and beyond}

As showed above, China's overall construction of its international identity has transformed towards a new Yinling Leading Power identity. The following sections will show how China has constructed its new identity through its changing climate engagement in the Paris era and beyond.

\section{Discursive construction}

With the transformation of China's overall identity construction towards a new Yinling Leading Power, this part will show that climate change governance has been recognized and framed as an important platform where China can play as a leading 
state and China's self-representation of a 'yinlingzhe' has accordingly dominated China's national narratives on its presence in global climate governance in the preand post-Paris period. Before the Paris Summit, China's former Vice-Foreign Minister and ambassador to France_-Jun Zhai (2015)_formally framed the Paris Summit as 'a platform in which China can play an international leadership role in global governance'. China's climate negotiators such as Qimin Chai (Interview 2017), Qingchen Chao (Interview 2017) and an expert member (Interview 2017) stressed that global climate governance is the 'world stage' of which China has been gradually at the 'centre' since Xi Jinping's rise to power in 2013. China official narratives framed itself as a 'yinlingzhe' in promoting international climate cooperation. For instance, China's state-owned newspaper People's Daily (2015 2016) repeatedly stressed that 'China's actions "yinling" global climate governance' and the world expects China to be 'a pioneer and an example for global efforts in combating climate challenge'. Chinese President Xi (2017b) concluded at the 19th Party's Congress: 'taking a driving seat in international cooperation to respond to climate change, China has become an important participant, contributor, and "yinlingzhe" in the global endeavour for ecological civilization'. Xi particularly linked the concept 'ecological civilization', which is rooted in China's past ecological philosophy, with his vision for China's international leadership and aimed to distinguish Chinese leadership from the traditional Western paradigms (Hansen et al. 2018). China's top climate negotiator Xie Zhenhua also emphasized that China has become an important 'yinlingzhe' in the global construction of ecological civilization (Chinanews 2017). Moreover, China's climate negotiator Qimin Chai stressed that:

China's self-positioning is transforming from a participant to a 'yinling$z$ he' in global climate governance. Since Xi Jinping became the President, China has become increasingly more proactive in global climate governance (Interview 2017).

An expert member of China's climate negotiation team also emphasized that:

In a long period, China insisted on representing itself as a developing country and avoided using 'leader' to define its role in global climate governance. Since Xi became the President, China has always represented itself as a 'yinlingzhe' (Interview 2017).

While its 'old' developing country discourses still exist, China's 'yinlingzhe' narratives and discursive construction of its leadership in promoting international climate cooperation have constituted the crucial part of its overall construction of the Yinling Leading Power identity. In China's national narratives, climate change governance has been transformed from a problem that developed countries should focus on to one of the most prominent domains that China shows international leadership and contributes to promoting international multilateral cooperation. Global climate governance has become one of China's prototypical discursive frames in constructing its new international identity.

China's identity reconstruction in climate governance is also discursively done through reconstructing issues of climate justice. Undertaking climate 
responsibility has been reconstructed from a heavy burden to China to its own positive duty and an important way to show its leadership. China's Xie Zhenhua (2015) has repeatedly stressed that 'addressing climate change is what China needs to fulfil its due international obligation as a responsible power'. Furthermore, China accepted, reconstructed and promoted a more flexible, balanced differentiation mechanism. For example, China and the USA together redefined the CBDR principle by adding a new qualifier- 'in light of different national circumstances' (Foreign Ministry 2014) and this new formulation was directly reiterated in the Paris Agreement. This new construction of the CBDR actually 'reduces the weight of the historical responsibility of developed countries', and its 'novel operationalization' - the Nationally Determined Contributions as a key mechanism in the Paris Agreement may ultimately result in 'the smallest common denominator in terms of climate justice' (von Lucke et al. 2021: 50-51). In addition to the reconstruction of those specific justice-related norms and principles, China's construction of distributive climate justice in terms of a fair climate deal also transformed from strictly embedding fairness into the established top-down model for developed countries to linking fairness with all Parties' voluntary contributions and highlighting inclusiveness. Moreover, by accepting and promoting the ideas of peaking emissions and carbon neutrality (see below), China's construction of climate justice regarding the right to emit and the exemption of developing countries from caps on emissions have also exhibited changes and flexibility.

\section{Policy practice}

The following parts will show how China has constructed its new identity through its proactive climate diplomacy and leadership building in climate governance since Xi's rise to power in 2013, and how climate governance has become an important platform where China seeks to share leadership with other major powers.

In the lead-up to Paris, China proactively cooperated with major powers to lead and promote international climate negotiations (Tiberghien 2018). For instance, China issued three bilateral joint statements on climate change with the USA and the EU, which paved the way for the success of the Paris Summit. In the three statements, the three sides made their relatively strong commitments, agreed to reach 'a protocol, another legal instrument or an agreed outcome with legal force under the Convention applicable to all Parties' (European Council 2015; Foreign Ministry 2014, 2015), and supported to include an enhanced transparency system with reporting and reviewing framework in the Paris outcome (Foreign Ministry 2015). Their efforts laid the basis for the historical agreement and many wordings of these statements were even directly adopted by the agreement (Tiberghien 2018).

Within the negotiations, just like the EU's bridge-building climate diplomacy (Oberthür and Groen 2017), China bridged the South and North through bilateral and multilateral diplomacy. In the run-up to Paris, China launched a series of intensive bilateral diplomacy with major players from the South and North as well as multilateral diplomacy within the BASIC group, the G77/China and the LikeMinded developing countries group to push different sides to converge on the 
common ground in specific issues such as climate finance and the differentiation framework (Wu 2016). In particular, it was China and the USA that played a pivotal role in securing the Paris Agreement (Kastner et al. 2018; Schreurs 2016; Tiberghien 2018). An EU high-level climate advisor argues that 'China is kind of a bridge between several worlds' and 'also playing a big role as a strong link with many parts of the world either through negotiating groups or loose alliances' (Interview 2018). In addition, China also proactively promoted climate change into other international multilateral institutions such as G20's Hangzhou Summit in 2016, where China and the USA announced the plans to ratify the Paris Agreement.

When the USA under the Trump administration withdrew from the Paris Agreement and retreated from global multilateralism, China did not downgrade its climate efforts. On the contrary, China stepped up its cooperation with the EU and other major players and jointly offered leadership to reach the Rulebook that makes the Agreement into a functioning GCG regime (Gurol and Starkmann 2021; Parker and Karlsson 2018).

Furthermore, China also wielded the climate leadership through two important approaches, i.e. leadership by example (Liefferink and Wurzel 2017) and providing international public goods (Dent 2008), in the Paris era. China has become an undisputable world leader and champion in investing renewable energy (AndrewsSpeed and Zhang 2019; REN21 2021). Regarding emission mitigation, China has undertaken more international responsibilities. In Paris, for instance, China for the first time committed to an exact peaking time for $\mathrm{CO}_{2}$ emissions (by around 2030) (Xi 2015a). Aside from that, China has achieved its 2020 emission reduction target, which is a carbon intensity reduction of 40 to $45 \%$ below 2005 levels, 3 years in advance (UN Climate Change News 2018). Furthermore, during the course of the COVID-19 pandemic in September 2020, Chinese President Xi revised the goal to peak emissions before 2030 and also announced that China will aim to achieve carbon neutrality before 2060 (Xinhuanet 2020). It is the first time that China committed to a long-term goal on emission reduction. China's Xie Zhenhua pointed out that 'this bold target may move global carbon neutrality ahead by 5-10 years' and will also 'play a key role in promoting stronger global climate governance' (China Dialogue 2020). Research published in Science magazine recently found that China's carbon neutrality target is largely consistent with the Paris Agreement goal of keeping global warming to $1.5^{\circ} \mathrm{C}$ (Duan et al. 2021). In addition, at the Leaders' Summit on Climate hosted by the USA in April 2021, Xi (2021) announced that China would strictly control coal-fired power projects, strictly restrict the growth in coal consumption in the 14th Five-Year Plan period (2021-2025) and gradually reduce it in the 15th Five-Year Period (2026-2030). Moreover, China's economy has already entered into a decoupling process between growth and $\mathrm{CO}_{2}$ emissions (IEA 2018; Tiberghien 2018). Regarding emission trading, China took experiences from the EU and established its own national Emission Trading System (ETS) in 2017 based on its national conditions and needs, which will become the world's largest ETS system once it is fully operational (Gippner 2020). China has not only offered considerable financial aids annually but also provided a large amount of projects around renewable energy technology transfer and offered personnel training courses to thousands of government officials, scholars and technicians from hundreds of developing 
countries (NDRC 2015). Through these domestic and international efforts, China showed its leadership by example regionally and internationally. In addition, as Christopher Dent (2008: 21) argued, providing international public goods is an important criteria of international leadership. At the 2015 China-US Summit and the Paris Summit, for example, President Xi announced that China will provide USD 3.1 billion to set up the China South-South Climate Cooperation Fund to support developing countries in combating climate change (Xi 2015a). The money even exceeds the pledge of USD three billion made by the USA to the UN's Green Climate Fund. It is a historical breakthrough that China contributed to international climate finance.

In brief, China has shown its leadership in the process of reaching and implementing the Paris Agreement. China's climate leadership has received a degree of international recognition. For instance, Charles Parker's research shows that China's climate leadership has received increasingly more recognitions from international negotiators and representatives of all delegations from 2009 to 2015 (Parker et al. 2017). The EU's Commissioner for climate action-Miguel Arias Cañete-also emphasized that the shared leadership of the EU and China in GCG is needed more than ever (European Commission 2017). An EU climate official pointed out that 'China is transiting from a developing country to a leading actor in climate governance' (Interview 2018). An EU principal climate advisor concluded that 'China is showing leadership by taking on more responsibilities' (Interview 2018). China's embrace of a shared leadership is quite similar to the EU's new approach since Paris that the EU acknowledged different pathways towards climate justice and wielded leadership through a more interactive way, i.e. being open to others' suggestions and negotiating their consent (von Lucke et al. 2021).

Notwithstanding that, China's negotiating behaviour, domestic climate policies and international practices have not been without doubts and criticism. Despite China's contribution to securing the Paris Agreement, some scholars and participant observers have noted that China's negotiating behaviour in Paris also undermined and impeded ambitious international efforts (Christoff 2016; Dimitrov 2016). Moreover, many scholars criticized that China's domestic climate policies are not being sufficiently ambitious (Harris 2017; Keohane 2017). In particular, China's greenhouse gas emissions continue to increase, with an average annual growth of $3.3 \%$ over the period 2010-2019 (Rhodium Group 2021), and new coal-fired power plants are still being built. In addition, as Robert Keohane emphasized, global climate leadership requires credibility and China has to endorse genuine transparency policies that make its climate commitments credible (Keohane 2017). Similarly, the EU's climate negotiators repeatedly complained in the interview with the author about the transparency problem of China's climate data and particularly urged China to be more transparent (Interview 2018). Furthermore, China's overseas investments in fossil fuels energy projects have sparked international criticism (Gupta and Chu 2018). For instance, in its newly released strategic document, the EU criticized China's construction of coal-fired power stations in many countries as undermining the global goals of the Paris Agreement (European Commission 2019). In order to be fully recognized as a credible climate leader, therefore, China has to self-reflect and adjust its future climate behaviours domestically and internationally. As China's 
Xie Zhenhua stressed, being a 'yinlingzhe' in GCG means China has to address climate change better at domestic, continually offer China's solutions on the basis of its evolving experience and practices, and provide 'bridging solution' for different sides within the international multilateral process on climate change (Chinanews 2017).

\section{Implications}

China's transforming identity construction, changing engagement in global climate governance with its changing construction of issues of climate justice have farreaching implications for China and other major actors such as the EU to cooperate and coordinate in strengthening global climate justice and promoting global climate governance.

Firstly, China's new identity construction with the climate leadership as its key feature will continue to constrain and reshape China's regional, interregional and global behaviours. China's high-profile interregional 'Belt and Road' initiative will be reviewed and assessed by the world in terms of its impacts on climate change. In order to gain wide participation and support, China has to put climate change into serious consideration in the projects of the 'Belt and Road' initiative.

Secondly, with China's transformation in climate governance, other emerging economies from the global South such as India and regional big developing countries are under increasing pressures to undertake greater but fairer responsibility for current and future emissions. Moreover, developed countries will suffer more moral and political pressures to essentially take the lead in addressing climate change and offer support to those poor and vulnerable developing countries.

Thirdly, China's recent climate proactiveness and its embrace of international climate leadership have already promoted and will continue to promote the cooperation between China and the EU in promoting the multilateral order of global governance and climate change governance in particular. The shared leadership of China and the EU will contribute to bridging the North-South gap in the follow-up international climate negotiations. Furthermore, the good and enduring climate relationship between China and the EU brings stability, certainty and dynamic to their bilateral relationship in a global context that is in flux.

Fourthly, China's reconstruction of climate change and issues of climate justice underpinned its convergence with developed countries especially the USA and contributed to breaking the complex 'dilemma' between climate justice and climate governance order. While the Paris Agreement has weakened the differentiation principle and distributive justice, the temporary but necessary trade-off between distributive justice-related concerns and the formation of an acceptable new comprehensive climate regime has a strong potential of strengthening global climate justice in the long term. Against the backdrop that the USA had launched a trade war and imposed sanctions against China, China has recently resumed its climate cooperation with the USA and attended the Leaders' Summit on Climate convened by the US administration under President Biden in April 2021, which provided new certainty and dynamic for promoting global climate governance and strengthening global climate justice in a world of uncertainty. 


\section{Conclusion}

This article offers an identity lens to understand China's changing engagement in global climate governance over the past decade. From the Copenhagen Climate Summit to the historical Paris Climate Summit, China has partially embedded the construction of its new Yinling Leading Power identity in leading global climate governance. This changing identity is both reflected in and partly constituted by the way China has come to take up its new leading role in global climate governance. Climate change governance has become one of China's prototypical discursive frames in constructing its new international identity through emphasising its role as a global leading actor.

On the road to Copenhagen, China attempted to maintain its developing country identity and its construction of climate justice as distributive justice in a North-South context. However, it suffered challenges from both the developed and developing world. With Xi Jinping's accession to power, China's international identity construction has been transforming towards a Yinling Leading Power. In the Paris era and beyond, China has reconstructed issues of climate justice and climate governance has become an important platform where China seeks to represent itself as a 'yinlingzhe' (leading state) and share leadership with other major powers. China's embrace of a shared leadership is similar to the EU's new interactive way to wielding climate leadership since Paris. China's climate leadership constitutes its new identity construction and becomes a key feature. China's transformation has far-reaching implications for strengthening global climate justice and promoting global climate governance. This article also points out that China's inadequate response to international expectations and lack of self-reflection in its climate policy have influenced international recognition on its climate leadership and new identity. In the post-Paris era, whether or not China fulfills its climate commitments, takes the lead in promoting global climate cooperation and gains sufficient recognition from other parties will have profound consequences for the prospects of this new identity construction, which has not yet been stabilized and secured.

Author contribution Sole author

Funding The author was funded by China Scholarship Council. Grant number 201506040034.

Data availability Not applicable

Code availability Not applicable

\section{Declarations}

Ethics approval Not applicable

Consent to participate Not applicable

Consent for publication Not applicable 
Conflict of interest The author declares no competing interests.

\section{References}

Andrews-Speed P, Zhang S (2019) China as a global clean energy champion: lifting the veil. Palgrave Macmillan, Singapore

Audet R (2013) Climate justice and bargaining coalitions: a discourse analysis. International Environmental Agreements: Politics, Law and Economics 13(3):369-386

Belis D, Joffe P, Kerremans B, Qi Y (2015) China, the United States and the European Union: multiple bilateralism and prospects for a new climate change diplomacy. Carbon \& Climate Law Review 9(3):203-218

Belis D, Schunz S (2013) China and the European Union: emerging partners in global climate governance? Environ Pract 15(3):190-200

Brzezinski Z (2009) The group of two that could change the world. https://www.ft.com/content/d9936 9b8-e178-11dd-afa0-0000779fd2ac. Accessed 15 August 2019

Chen D (2017) Is China ready for global leadership. https://thediplomat.com/2017/02/is-china-ready-forglobal-leadership/. Accessed 10 February 2019

China Dialogue (2020) China's new carbon neutrality pledge: what next? https://chinadialogue.net/en/ climate/chinas-new-carbon-neutrality-pledge-what-next/. Accessed 24 September 2020

Chinanews (2017) Zhuanfang Xiezhenhua: Zhongguo jiangruhe gaishan quanqiuqihouzhili "daqihou”? (Interview Xie Zhenhua: how will China improve the 'grand climate' of global climate governance?). http://www.chinanews.com/gn/2017/11-13/8375380.shtml. Accessed 14 September 2019

Christoff P (2010) Cold climate in Copenhagen: China and the United States at COP15. Environ Polit 19(4):637-656

Christoff P (2016) The promissory note: COP 21 and the Paris Climate Agreement. Environ Polit 25(5):765-787

Conrad B (2012) China in Copenhagen: reconciling the "Beijing climate revolution" and the "Copenhagen climate obstinacy." The China Quarterly 210:435-455

Dent CM (2008) What region to lead? Developments in East Asian regionalism and questions of regional leadership. In: Dent CM (ed) China, Japan and regional leadership in East Asia. Edward Elgar Publishing, Cheltenham, pp 3-33

Dimitrov RS (2010) Inside UN climate change negotiations: the Copenhagen conference. Rev Policy Res 27(6):795-821

Dimitrov RS (2016) The Paris agreement on climate change: behind closed doors. Glob Environ Polit 16(3):1-11

Dong L (2017) Bound to lead? Rethinking China's role after Paris in UNFCCC negotiations Chinese. J Popul Resour Environ 15(1):32-38

Duan $\mathrm{H}$ et al (2021) Assessing China's efforts to pursue the $1.5^{\circ} \mathrm{C}$ warming limit. Science 372(6540):378-385

Eckersley R (2020) Rethinking leadership: understanding the roles of the US and China in the negotiation of the Paris Agreement. Eur J Int Rel 26(4):1178-1202

ENB (1997) Report of the meetings of the FCCC subsidiaries: 20-31 October 1997. The International Institute for Sustainable Development 12(66). http://enb.iisd.org/download/pdf/enb1266e.pdf

ENB (2009) Copenhagen highlights: Wednesday, 9 December 2009. The International Institute for Sustainable Development 12(451). http://enb.iisd.org/download/pdf/enb12451e.pdf

Engels A (2018) Understanding how China is championing climate change mitigation. Palgrave Commun 4(1):1-6

European Commission (2009) Towards a comprehensive climate change agreement in Copenhagen https://eur-lex.europa.eu/LexUriServ/LexUriServ.do?uri=COM:2009:0039:FIN:EN:PDF. Accessed 17 December 2017

European Commission (2017) Commissioner Arias Cañete in China to strengthen climate and clean energy ties. https://ec.europa.eu/clima/news/commissioner-arias-ca\%C3\%B1ete-china-strengthen-climate-and-cleanenergy-ties_en. Accessed 10 March 2018

European Commission (2019) EU-China - a strategic outlook. https://ec.europa.eu/commission/sites/ beta-political/files/communication-eu-china-a-strategic-outlook.pdf. Accessed 2 April 2019 
European Council (2015) EU-China joint statement on climate change. https://www.consilium.europa.eu/ media/23733/150629-eu-china-climate-statement-doc.pdf. Accessed 14 March 2018

Foreign Ministry (2014) China-US joint announcement on climate change. https://www.mfa.gov.cn/chn// gxh/zlb/smgg/t1210034.htm. Accessed 20 December 2017

Foreign Ministry (2015) U.S.-China joint presidential statement on climate change. https://www.mfa.gov. $\mathrm{cn} / \mathrm{chn} / / \mathrm{gxh} / \mathrm{zlb} / \mathrm{smgg} / \mathrm{t} 1300787 . \mathrm{htm}$. Accessed 20 December 2017

Gippner O (2020) Creating China's climate change policy: internal competition and external diplomacy. Edward Elgar Publishing, Cheltenham

Gupta J, Chu E (2018) Inclusive development and climate change: the geopolitics of fossil fuel risks in developing countries. African and Asian Studies 17(1-2):90-114

Gurol J, Starkmann A (2021) New partners for the planet? The European Union and China in international climate governance from a role-theoretical perspective. J. Common Mark. Stud. 59(3):518-534

Hansen MH, Li H, Svarverud R (2018) Ecological civilization: interpreting the Chinese past, projecting the global future. Glob Environ Chang 53:195-203

Harris PG (2017) China's Paris pledge on climate change: inadequate and irresponsible. J Environ Stud Sci 7(1):102-107

Harris PG, Chow AS, Karlsson R (2013) China and climate justice: moving beyond statism. International Environmental Agreements: Politics, Law and Economics 13(3):291-305

He Y (2009) Zhongguo zizhu jianpaixingdong wufujiatiaojian yeburongtanpan (China's voluntary mitigation actions have no strings attached and are not negotiable). http://world.people.com.cn/GB/ 8212/14450/46162/10567346.html. Accessed 17 January 2018

Heggelund GM (2021) China's climate and energy policy: at a turning point? International Environmental Agreements: Politics, Law and Economics 21(1):9-23

Hilton I, Kerr O (2017) The Paris Agreement: China's 'New Normal'role in international climate negotiations. Clim Pol 17(1):48-58

Hochstetler K, Milkoreit M (2014) Emerging powers in the climate negotiations: shifting identity conceptions. Polit Res Q 67(1):224-235

Hopf T (1998) The promise of constructivism in international relations theory. Int Secur 23(1):171-200

Hu J (2004) Tuijin hezuogongying, shixian chixufazhan (Promote cooperation and win-win, achieve sustainable development). https://www.fmprc.gov.cn/ce/cohk/chn/jb/zt/2004zt/APEC2004/t170951. htm. Accessed 12 July 2018

Hu J (2011) Zai Zhongguo jiaru shijiemaoyizuzhi 10 zhounian gaocengluntan shangde jianghua (Speech at the Forum to commemorate the 10th anniversay of China's entry into the WTO). http://www.mofcom.gov.cn/article/ae/ai/201112/20111207873587.shtml. Accessed 12 July 2018

IEA (2018) Global energy \& $\mathrm{CO}_{2}$ status report. https://mehi.hu/sites/default/files/geco2017.pdf. Accessed 3 October 2019

Kasa S, Gullberg AT, Heggelund G (2008) The Group of 77 in the international climate negotiations: recent developments and future directions. International Environmental Agreements: Politics, Law and Economics 8(2):113-127

Kastner SL, Pearson MM, Rector C (2018) Climate change negotiations: from hold-up to invest. In: Kastner SL, Pearson MM, Rector C (eds) China's strategic multilateralism: investing in global governance. Cambridge University Press, New York, pp 173-216

Keohane R (2017) The international climate regime without American leadership. Chinese Journal of Population Resources and Environment 15(3):184-185

Keohane R, Oppenheimer M (2016) Paris: beyond the climate dead end through pledge and review? Politics and Governance 4(3):142-151

Kobayashi Y (2003) Navigating between "luxury" and "survival" emission: tensions in China's multilateral and bilateral climate change diplomacy. In: Harris PG (ed) Global warming and East Asia: the domestic and international politics of climate change. Routledge, London, pp 86-108

Li P (1992) Lipengzongli zai lianheguo huanfadahui shounaohuiyi shangde jianghua (Speech by Premier Li Peng divered at the United Nations summit conference on environment and development). General Office of the State Council of China, Beijing

Liefferink D, Wurzel RK (2017) Environmental leaders and pioneers: agents of change? J Eur Publ Policy 24(7):951-968

Mearsheimer JJ (2010) The gathering storm: China's challenge to US power in Asia. The Chinese Journal of International Politics 3(4):381-396

Men H (2014) China's national identity in transition: domestic and international perspectives (1982-2012). Social Sciences in China 35(2):189-207 
Men H (2017) Yingdui quanqiuzhili weiji yu biange de zhongguofanglve (China's strategy for approaching the crisis and reform of global governance). Zhongguo shehuikexue (Social Sciences in China) (10):36-46

Climate change and EU-China partnership: realist disguise or institutionalist blessing?Men J (2014) Climate change and EU-China partnership: realist disguise or institutionalist blessing? Asia Europe Journal 12(1-2):49-62

Messari N (2001) Identity and foreign policy: the case of islam in US foreign policy. In: Kubálková V (ed) Foreign policy in a constructed world. M. E. Sharpe, New York, pp 227-246

NDRC (2009) Implementation of the Bali roadmap China's position on the Copenhagen climate change conference. http://www.china-un.ch/eng/bjzl/t564324.htm.

NDRC (2015) China's policies and actions for addressing climate change (2015). http://en.ccchina.org.cn/ archiver/ccchinaen/UpFile/Files/Default/20151120095849657206.pdf.

Oberthür S, Groen L (2017) The European Union and the Paris Agreement: leader, mediator, or bystander? WIREs Climate Change 8(1):e445

Okereke C, Coventry P (2016) Climate justice and the international regime: before, during, and after Paris. Wiley Interdisciplinary Reviews: Climate Change 7(6):834-851

Ong LH (2012) The apparent "paradox" in China's climate policies. Asian Surv 52(6):1138-1160

Pang Z (2018) Zhongguo zaiquanqiuzhilizhong dangangshenmejuese? Zhongguoban "Feibaquan de guojilingdao" (What kind of role does China play in global governance? The Chinese version "non-hegemonic ledership"). http://www.chinatimes.cc/article/73848.html. Accessed 27 March 2018

Parker CF, Karlsson C (2018) EU climate leadership in Katowice helped deliver the deal on the Paris Agreement rulebook. https://blogs.lse.ac.uk/europpblog/2018/12/20/eu-climate-leadership-in-katowice-helpeddeliver-the-deal-on-the-paris-agreement-rulebook/. Accessed 20 September 2019

Parker CF, Karlsson C, Hjerpe M (2017) Assessing the European Union's global climate change leadership: from Copenhagen to the Paris Agreement. J Eur Integr 39(2):239-252

People's Daily (2015) Yinling quanqiuqihouzhili de Zhongguozuowei (China's practices in leading global climate governance). http://opinion.people.com.cn/n/2015/1208/c1003-27898232.html. Accessed 29 July 2018

People's Daily (2016) Jianding yinling quanqiuqihouzhili jincheng (Firmly leading the process of global climate governance). http://cpc.people.com.cn/pinglun/n1/2016/0424/c78779-28299932.html. Accessed 29 July 2018

$\mathrm{Pu}$ X (2017) Controversial identity of a rising China. The Chinese Journal of International Politics 10(2):131-149

REN21 (2021) Renewables 2021 global status report. https://www.ren21.net/wp-content/uploads/2019/05/ GSR2021_Full_Report.pdf

Rhodium Group (2021) Preliminary 2020 greenhouse gas emissions estimates for China. https://rhg.com/ research/preliminary-2020-greenhouse-gas-emissions-estimates-for-china/. Accessed 10 August 2021

Schreurs MA (2016) The Paris climate agreement and the three largest emitters: China, the United States, and the European Union. Politics and Governance 4(3):219-223

Shambaugh D (2011) Coping with a conflicted China. Wash Q 34(1):7-27

Shue H (1992) The unavoidability of justice. In: Hurrell A, Kingsbury B (eds) The international politics of the environment: actors, interests, and institutions. Oxford University Press, Oxford, pp 373-397

Shue H (1993) Subsistence emissions and luxury emissions. Law \& Policy 15(1):39-60

Stalley P (2013) Principled strategy: the role of equity norms in China's climate change diplomacy. Glob Environ Polit 13(1):1-8

State Council (2019) China and the world in the new era. http://www.xinhuanet.com/politics/2019-09/27/c_ 1125047331.htm.

Tiberghien Y (2018) Chinese global climate change leadership and its impact. In: Amighini A (ed) China champion of (which) globalisation? Ledizioni LediPublishing, Milan, pp 101-120

UN Climate Change News (2018) China meets 2020 carbon target three years ahead of schedule. https:// unfccc.int/news/china-meets-2020-carbon-target-three-years-ahead-of-schedule. Accessed 13 june 2021

Lucke von F, Diez T, Aamodt S, Ahrens B 2021 The EU and global climate justice: normative power caught in normative battles Routledge New York

Wang Y (2015) 2015: A year of flying colors for pursuing Major-Country Diplomacy with distinctive Chinese features. https://www.fmprc.gov.cn/mfa_eng/wjdt_665385/zyjh_665391/t1329609.shtml. Accessed 15 June 2018

Wen J (2007) Wen Jiabao's speech at the Third East Asia summit. http://www.gov.cn/ldhd/2007-11/22/conte nt_812088.htm.

Wen J (2009) Build consensus and strengthen cooperation to advance the historical process of combating climate change. https://www.fmprc.gov.cn/mfa_eng/wjdt_665385/zyjh_665391/t647091.shtml. 
Wendt A (1999) Social theory of international politics. Cambridge University Press, New York

Wu F (2016) Shaping China's climate diplomacy: wealth, status, and asymmetric interdependence. J Chin Polit Sci 21(2):199-215

Xi J (2012) Xieshouhezuo gongtongweihu shijieheping yu anquan (Work together to maintain the peace and security of the world). https://www.fmprc.gov.cn/web/ziliao_674904/zyjh_674906/t948833.shtml. Accessed 1 August 2018

Xi J (2013) Jiang lianglichengdan gengduoguojizeren (China will undertake more international responsibility based on its capability). http://theory.people.com.cn/n/2013/0320/c49150-20848996.html. Accessed 1 August 2018

Xi J (2014) Jiakuai ziyoumaoyiqu zhanlve jiakuai goujian kaifangxing jingji xintizhi (Accelerating the implementation of the strategy of free trade zone, speeding up the construction of an open economic system). http://www.xinhuanet.com//politics/2014-12/06/c_1113546075.htm. Accessed 3 September 2017

Xi J (2015a) Work together to build a winwin, equitable and balanced governance mechanism on climate change. https://unfccc.int/sites/default/files/cop21cmp11_leaders_event_china.pdf. Accessed 3 September 2017

Xi J (2015b) Xieshougoujian hezuogongying xinhuoban, tongxindazao renleimingyungongtongti (Work together to build a new partnership of win-win cooperation, build a community of shared future for mankind). http://jhsjk.people.cn/article/27644987. Accessed 3 September 2018

Xi J (2016a) Jiandingxinxin gongmoufazhan (Firm up confidence and seek common development). https:// www.fmprc.gov.cn/web/ziliao_674904/zyjh_674906/t1406096.shtml. Accessed 3 September 2017

Xi J (2016b) Zhongguofazhan xinqidian, quanqiuzengzhang xinlantu (A new start of China's development, a new blueprint of global growth). http://www.xinhuanet.com/mrdx/2016-09/04/c_135658789.htm. Accessed 3 September 2018

Xi J (2017a) Gongtonggoujian renleimingyungongtongti (Jointly build a community of shared future for mankind). http://www.xinhuanet.com/world/2017-01/19/c_1120340081.htm. Accessed 1 August 2018

Xi J (2017b) Secure a decisive victory in building a moderately prosperous society in all respects and strive for the great success of socialism with Chinese characteristics for a new era. http://www.xinhuanet.com/ english/download/Xi_Jinping's_report_at_19th_CPC_National_Congress.pdf.

Xi J (2021) For Man and nature: building a community of life together. http://www.xinhuanet.com/english/ 2021-04/22/c_139899289.htm. Accessed 25 April 2021

Xie Z (2015) Quanqiuqihouzhili xunqiu zuidagongyueshu (Global climate governance seeks "the greatest common divisor"). http://theory.people.com.cn/n/2015/1130/c136457-27870970.html.

Xinhuanet (2020) Xi Focus: Xi announces China aims to achieve carbon neutrality before 2060. http://www. xinhuanet.com/english/2020-09/23/c_139388764.htm. Accessed 10 December 2020

Yan X (2014) From keeping a low profile to striving for achievement. The Chinese Journal of International Politics 7(2):153-184

Yu Q (2009a) Ambassador Yu Qingtai holds a briefing for Chinese and foreign media. https://www.fmprc. gov.cn/ce/cein/eng/zgbd/t577413.htm. Accessed 17 January 2018

Yu Q (2009b) Yu Qingtai dashi juxing zhongwaimeiti chuifenghui (Ambassador Yu Qingtai holds a briefing for Chinese and foreign media). http://ipc.fmprc.gov.cn/chn/cfh/t629331.htm. Accessed 17 January 2018

Yu Q (2010) China’s interests must come first. https://www.chinadialogue.net/article/show/single/en/3792China-s-interests-must-come-first. Accessed 20 May 2017

Zhai J (2015) Responsibility and opportunities at the Paris climate conference. http://politics.people.com. $\mathrm{cn} / \mathrm{n} / 2015 / 1127 / \mathrm{c} 1001-27862366 . h t m l$. Accessed 20 July 2018

Publisher's note Springer Nature remains neutral with regard to jurisdictional claims in published maps and institutional affiliations. 